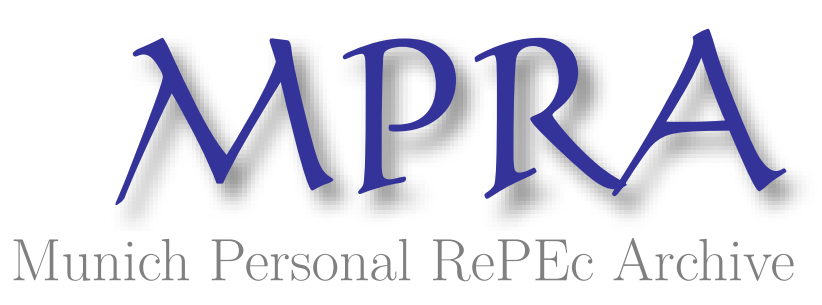

\title{
Measuring the Impact of Cash Crops on Household Expenditure and Poverty in Rural Viet Nam
}

\author{
Nguyen Viet, Cuong
}

Faculty of Trade and International Economics, National Economics University, Viet Nam.

20 April 2008

Online at https://mpra.ub.uni-muenchen.de/24921/

MPRA Paper No. 24921, posted 15 Sep 2010 01:24 UTC 


\title{
Measuring Impact of Cash Crops on Household Expenditure and Poverty in Rural Viet Nam
}

\author{
Nguyen Viet Cuong ${ }^{1}$
}

\begin{abstract}
This paper measures the impacts of cash crops on household consumption expenditure and poverty in rural Vietnam using data from Viet Nam Household Living Standard Surveys in 2002 and 2004. It is found that revenues from cash crops have positive and statistically significant impacts on per capita expenditure. More specifically, an increase of one Viet Nam Dong (VND) in rice revenues leads to an increase of 0.019 VND in per capita expenditure, and the corresponding figures for revenues of annual crops, perennial crops, and fruits are $0.038,0.040$ and 0.036 respectively. As a result, the crop sales have positive and statistically significant impacts on poverty reduction of the crop-growing households and rural population. The poverty-reducing impacts are found to be positive for all the three Foster-Greer-Thorbecke poverty measures.
\end{abstract}

Keywords: Cash crop, agriculture, farm households, household expenditure, poverty, Viet Nam.

JEL classification: I32; Q12; Q18

\footnotetext{
${ }^{1}$ Indochina Research \& Consulting, Hanoi, Vietnam.

Email: c_nguyenviet@yahoo.com
} 


\section{INTRODUCTION}

It is often argued that crop production has an important role in economic development and poverty reduction. The crop production can contribute to economic growth through different channels such as provision of food and employment generation (e.g., see Johnston and Mellor, 1961; Ranis and others, 1990; Irz and others, 2001; Timmer, 2002, etc.). Agricultural growth can result in remarkable reduction in poverty (e.g., Thorbecke and Jung, 1996). Together with trade liberalization trend, it can bring important sources of income from exportation. ${ }^{2}$

However, when integrated into the global economy, the crop sector of a country can be adversely affected by global economic shocks. A channel for shock transmission is the price of output and inputs (Winters et. al., 2004; Easterly and Kraay, 2000). A sudden decrease in the price of crop outputs can quickly push the poor households who produce crops into losses and poverty. Coffee growing in Viet Nam is an example. In the late 1990s, the price of coffee was very high in the world market, and many households in the Tay Nguyen province grew coffee. However, after that the coffee price was suddenly dropped, which affected many households afflicted, since there were 80 per cent of the poor households who grew coffee in Tay Nguyen (World Bank, 2004). The farmers often bought the production inputs with delayed payments, and as the coffee price fell down, they became indebted, and had to sell their land to pay the debts. Another example can be the harmful impact of reduction in corn price in Mexico. Poor farmers could not respond to decrease in price of corn, and suffered from losses in incomes from corn production (Levy and Wijnbergen, 1992; Nadal, 2000).

In addition, the industry and service sectors tend to grow more quickly than the agricultural sector in the long run. The shrinking of agriculture relative to industry and service has been observed in both developed and developing countries. The non-farm employment and business have been proved to be an effective way to increase household income and reduce poverty (e.g., Lanjouw and Lanjouw, 1995; Lanjouw, 1998; Van de Walle, 1994; Ruben and van den Berg, 2001).

Viet Nam has been an agricultural country, with around 60 per cent of the population involved in the crop production in 2006. It is also one of leading countries in exporting rice, coffee, and tea. The export value of agricultural products increased from

\footnotetext{
${ }^{2}$ The role of trade liberalization is discussed in numerous studies e.g., Harrison (2005); Winters and others (2004); and McCulloch and others (2001).
} 
24,500 billion VND to 100,200 billion VND during the period 1995-2006. ${ }^{3}$ However, the share of crop products in total export revenues was reduced from 32 to 14 per cent during this period. It is not clear whether the cash crops still make important contribution to household consumption and poverty reduction. The main objective of this paper is to measure impacts of households' sales of different crops on per capita expenditure and poverty reduction. Information from the study can be helpful for policy makers in designing programs and policies related to the crop production. Data used in this paper are from Viet Nam Household Living Standard Surveys in 2002 and 2004.

There are six sections in this paper. The second section describes data sources used in this paper. The third section gives brief overview of the cash crop production and household welfare in Viet Nam. Next, the fourth section presents methodology of impact evaluation of crop sales. The fifth section presents empirical findings on impact estimation. Finally, the sixth section concludes.

\section{DATA SET}

The study relies on data from the two recent Viet Nam Household Living Standard Surveys (VHLSS), which were conducted by the General Statistics Office of Viet Nam (GSO) with technical support from the World Bank (WB) in the years 2002 and 2004. The 2002 and 2004 VHLSSs covered 30,000 and 9,000 households, respectively.

The samples are representative for the national, rural and urban, and regional levels. It should be noted that GSO increased the sample size of the 2002 VHLSS to 30,000 households so that the data could be representative for some large provinces. However, this large sample survey was very expensive, and the sample size of VHLSS 2004 was reduced to 9,000 households. The 2002 and 2004 VHLSSs set up a panel of 4000 households, which are representative for the whole country, and for the urban and rural population.

The surveys collected information through household and community level questionnaires. Information on households includes basic demography, employment and labor force participation, education, health, income, expenditure, housing, fixed assets and durable goods, participation of households in poverty alleviation programs.

Expenditure and income per capita are collected using very detailed questionnaires in VHLSS. Expenditure includes food and non-food expenditure. Food expenditure

\footnotetext{
${ }^{3} 1$ USD is approximately 16000 VND in January 2006.
} 
includes purchased food and foodstuff and self-produced products of households. Nonfood expenditure comprises expenditure on education, healthcare expenditure, expenditure on houses and commodities, and expenditure on power, water supply and garbage. Regarding the income, household income can come from any source. Income includes income from agricultural and non-agricultural production, salary, wage, pension, scholarship, income from loan interest and house rental, remittances and social transfers. Income from agricultural production comprises crop income, livestock income, aquaculture income, and income from other agriculture-related activities.

Information on commune characteristics was collected from 2,960 and 2,181 communes in the 2002 and 2004 surveys, respectively. Data on commune characteristics consist of demography and general situation of communes, general economic conditions and aid programs, non-farm employment, agricultural production, local infrastructure and transportation, education, health, and social affairs. Commune data can be linked with household data. However, the commune data in the 2004 VHLSS are only available for rural areas.

This study focuses on the rural population. The main reason is that commune variables are used in regression analysis of the transfer impact, and there are only data on commune variables for rural areas in the 2004 VHLSS. In addition, poverty in Viet Nam is mostly a rural phenomenon, with 95 per cent of all poor living in rural areas in 2004. The number of households in the rural panel for 2002-2004 is 3,099.

\section{CASH CROP PRODUCTION AND HOUSEHOLD WELFARE IN VIET NAM}

In this paper, the cash crops are defined as crops that households grow for sale. The cash crops consist of rice, industrial perennial crops (rubbers, coffee, tea, peanut, cashew nuts, and pepper), fruit and annual crops. Annual crops include sugar-cane, vegetables, potato, maize, and other annual crops. The value of cash crops increased at an annual growth rate of 6 per cent during the period 1995-2006. However, there is an evidence of shrinking of the agricultural sector in the economy. Figure 1 presents the share of the crop value in GDP over time. It shows that this share was decreased from 23 to 15 per cent during the period 1995-2006. 
Figure 1. Share of the crop value in GDP

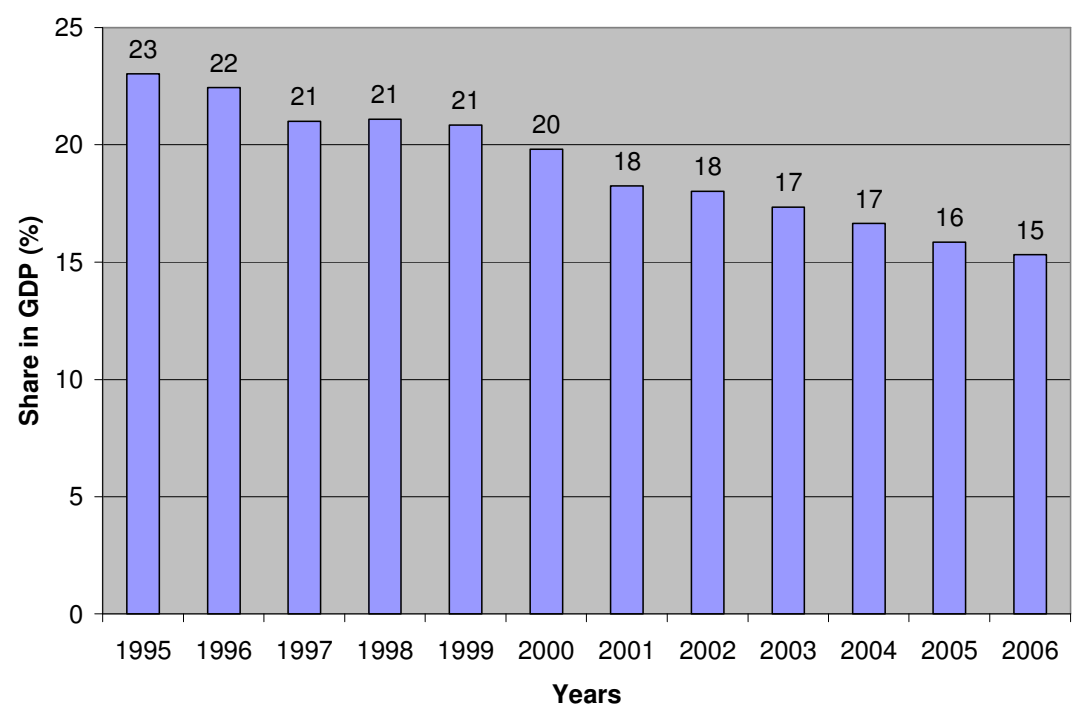

Source: Statistical Year Books of General Statistical Office of Viet Nam

In addition, the share of agricultural products in total export revenues was reduced more quickly. Figure 2 shows that this share went down from 32 per cent in 1995 to 14 per cent in 2006.

Figure 2. Share of crop exports in total export revenues

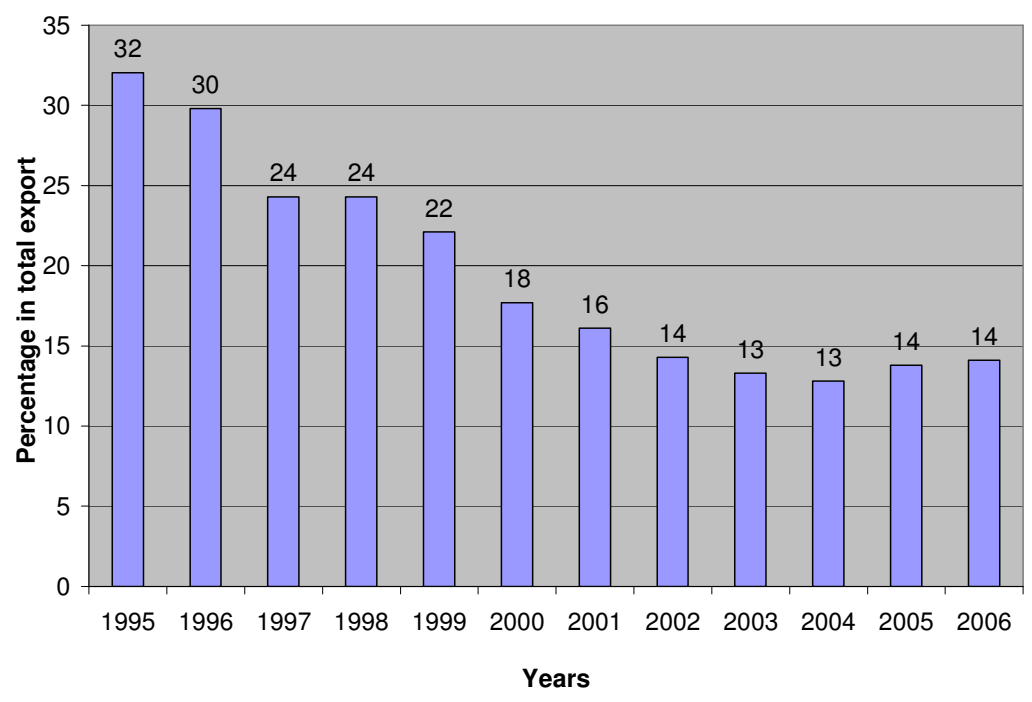

Source: Statistical Year Books of General Statistical Office of Viet Nam

Although, the share of agriculture in GDP tends to decrease overtime, the proportion of households involved in agriculture remains rather high in rural Viet Nam. Figure 3 presents the percentage of rural households producing cash crops in the period 2002-2004. It shows that the ratio of households producing cash crops increased from 69 
to 72 per cent. The proportion of households producing each crop type also increased. It should be noted that the proportion of households producing all crops were larger than the proportion of the households producing cash crops (crops for sale), since there were households growing crops for consumption. The proportion of households producing crops in rural areas was reduced slightly from 82 to 81 per cent during the period 20022004.

Figure 3. Percentage of households producing cash crops

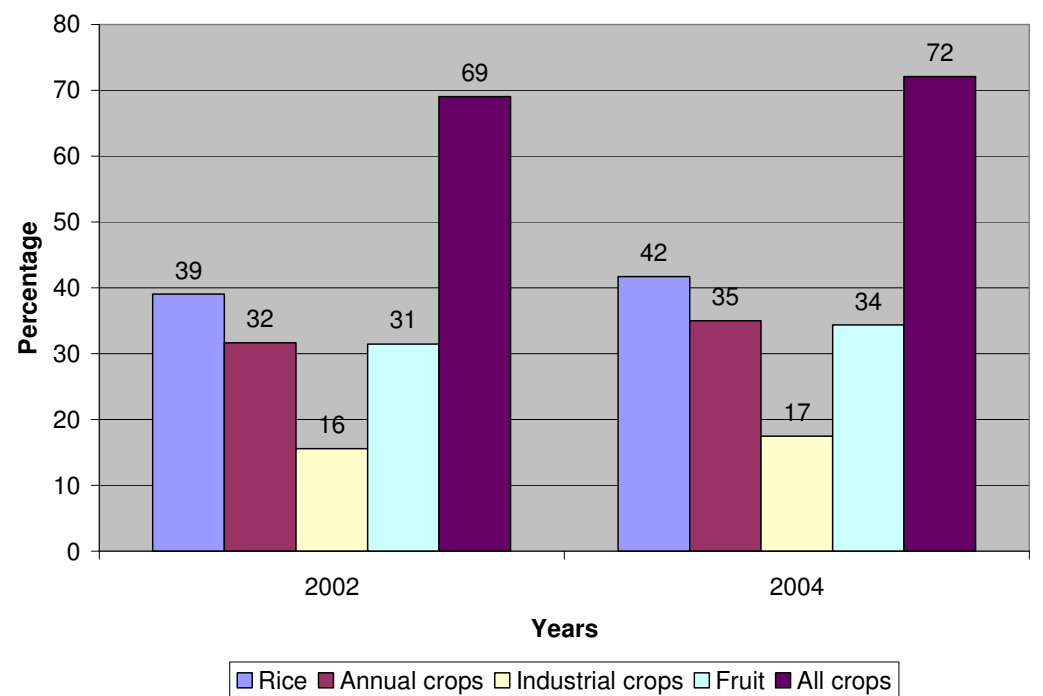

Source: Estimation from VHLSSs 2002 and 2004

Figure 4. Per capita expenditure of households with and without cash crops

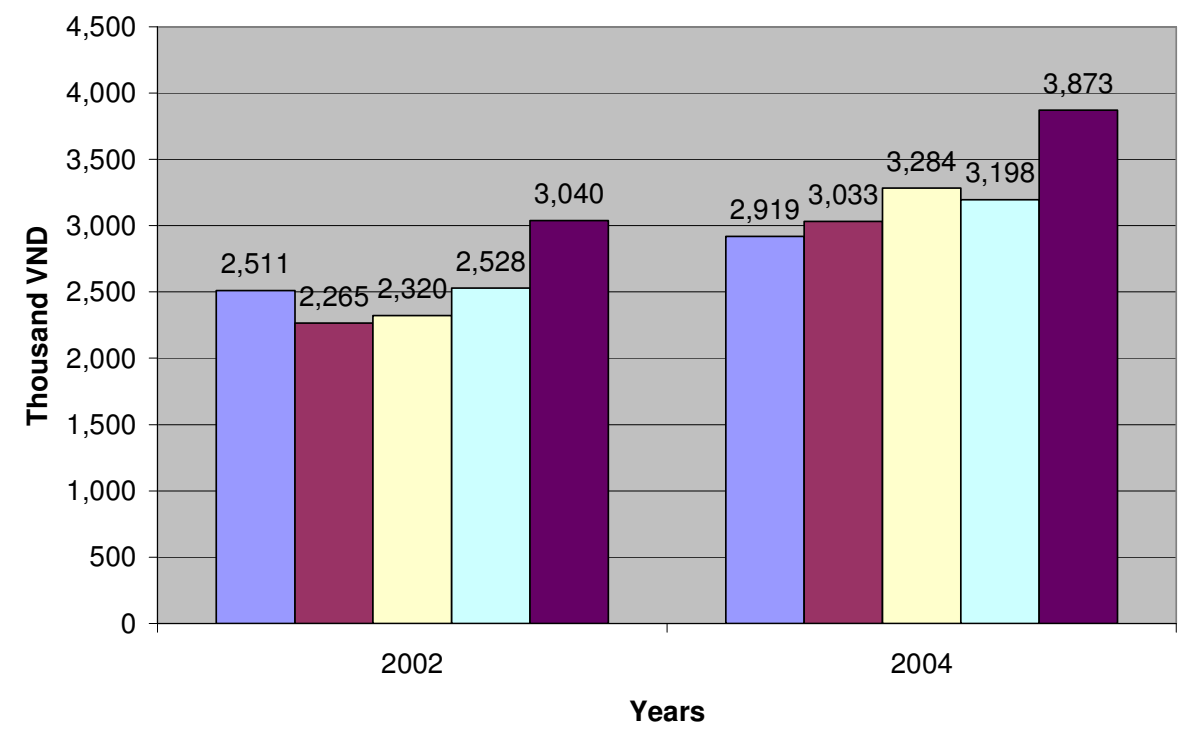

$\square$ Rice $\square$ Annual crops $\square$ Industrial crops $\square$ Fruit $\square$ No crop

Source: Estimation from VHLSSs 2002 and 2004 
Households without cash crops tended to have higher consumption expenditure and lower poverty than those with cash crops (Figure 4 and 5). Among the cash crop households, households with industrial crops experienced the highest growth rate of expenditure during 2002-2004.

All the household groups had experienced poverty reduction during the period 2002-2004. Households with rice sale had the lowest poverty incidence than households with other crops (annual and industrial crops), meanwhile, households with industrial crops had the highest poverty incidence.

Figure 5. Poverty incidence of households with and without cash crops (in per cent)

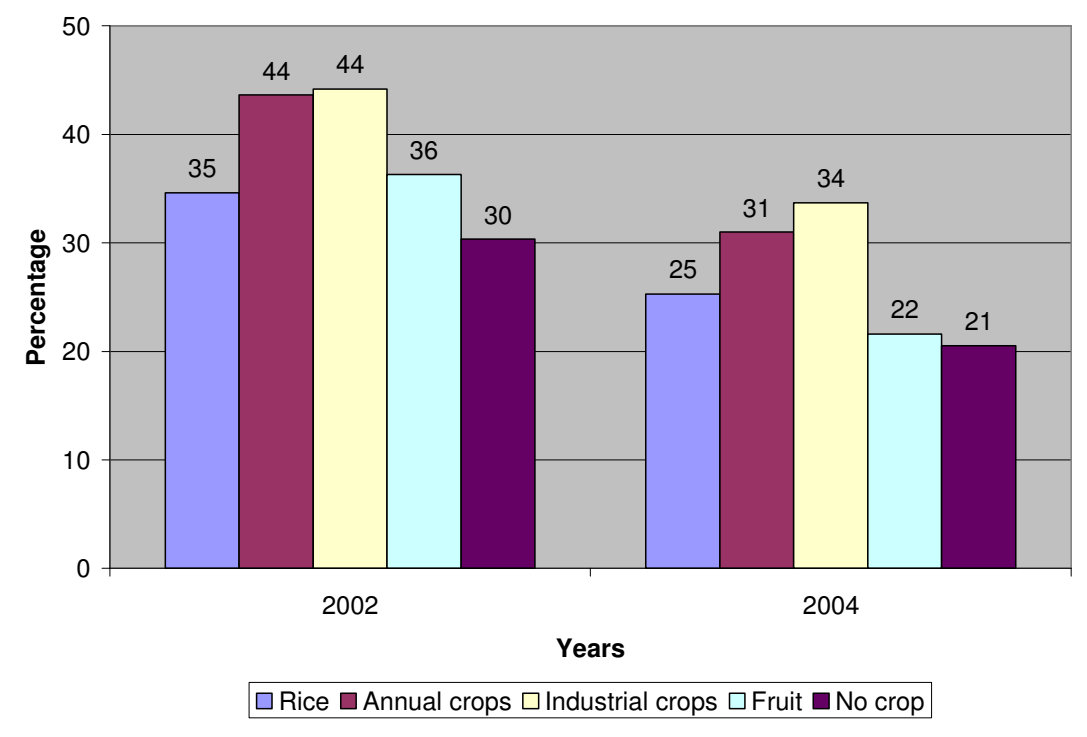

Source: Estimation from VHLSSs 2002 and 2004

\section{METHODS OF IMPACT MEASUREMENT}

\section{Impact on Household Consumption Expenditure}

This section presents the method to measure impacts of crop sales on household consumption expenditure and poverty. In this paper, expenditure is assumed to be a linear and a semi-log linear function of household characteristics:

$Y_{i}=\alpha+X_{i} \beta+D_{i} \gamma+\varepsilon_{i}$,

$\ln \left(Y_{i}\right)=\alpha+X_{i} \beta+D_{i} \gamma+\varepsilon_{i}$, 
where $Y_{i}$ is per capita expenditure of household $i ; X_{i}$ are household characteristics; and $D_{i}$ is a vector of are revenues of crops including rice, annual crops, industrial crops and fruit crops from the crop-growing households. Crop revenues are money that households obtain from crop sales. ${ }^{4}$ The impact of $D$ is estimated using the both functions to examine the sensitivity of impact estimates to different functions of outcome. ${ }^{5}$

Since $D$ are continuous variables, one is often interested in the marginal effect (ME), which is the derivative of $Y$ with respect to $D$. For equations (1) and (2), ME is equal to:

$$
\begin{aligned}
& M E=\frac{\partial Y}{\partial D}=\gamma, \\
& M E=\frac{\partial Y}{\partial D}=e^{\left(\alpha+X_{i} \beta+D_{i} \gamma+\varepsilon_{i}\right)}(\gamma)=Y_{i} \gamma,
\end{aligned}
$$

respectively.

Since ME in the semi-log function of outcome varies across the outcome value, one can use the Average Partial Effect (APE) to measure the impact of $D$ (Wooldridge, 2001). In this paper, we define the Average Partial Effect on the Treated (APET), which measures how the average impact on the crop-selling households changes due to a small change in crop revenues.

In the case of equation (1), APET is equal to ME, and it is estimated by $\hat{\gamma}$. In the case of equation (2), APET is expressed as follows:

$$
A P E T=E\left(\frac{\partial Y}{\partial D} \mid D>0\right)=E\left(Y_{i} \gamma \mid D_{i}>0\right)
$$

Thus the estimator is given by:

$$
A P \hat{E} T=\frac{1}{n_{p}} \sum_{i=1}^{n_{p}}\left(Y_{i} \hat{\gamma}\right)
$$

where $n_{p}$ is the number of the crop-selling households. The standard error of the estimates is calculated using a bootstrap technique.

The difficulty in estimating the effect of the crop sales is endogeneity of the crop sales. Unobserved variables such working conditions, production and business skills, and information can be correlated with the crop sales. This paper uses instrumental-variables

\footnotetext{
${ }^{4}$ Income is defined as revenues minus costs.

${ }^{5}$ We do not use the double-log function, i.e., $\ln \left(Y_{i}\right)=\alpha+X_{i} \beta+\ln \left(D_{i}\right) \gamma+\varepsilon_{i}$, since for households without crops, we get missing values of $\ln \left(D_{i}\right)$.
} 
regressions and fixed-effect regressions to correct for the endogeneity of the crop sales in the expenditure equation.

\section{Impact on Poverty}

In this paper, poverty is measured by three Foster-Greer-Thorbecke poverty indexes which can all be calculated using the following formula (Foster, Greer and Thorbecke, 1984):

$P_{\alpha}=\frac{1}{n} \sum_{i=1}^{q}\left[\frac{z-Y_{i}}{z}\right]^{\alpha}$,

where $Y_{i}$ is a welfare indicator (consumption expenditure per capita in this paper) for person $i, z$ is the poverty line, $n$ is the number of people in the sample population, $q$ is the number of poor people, and $\alpha$ can be interpreted as a measure of inequality aversion.

When $\alpha=0$, we have the headcount index $\mathrm{H}$ which measures the proportion of people below the poverty line. When $\alpha=1$ and $\alpha=2$, we have the poverty gap $P_{2}$ which measures the depth of poverty, and the squared poverty gap $P_{2}$ which measures the severity of poverty, respectively.

Impact of crop sales on an index of poverty of the recipients is expressed as follows:

$\Delta P=P(D>0, Y)-P\left(D>0, Y_{(D=0)}\right)$,

where the first term on the left-hand side of (8) is the poverty measure of the crop-selling households in the presence of crop revenues. This term is observed and can be estimated directly from the sample data. However, the second term on the left-hand side of (8) is the counterfactual measure of poverty, i.e., poverty indexes of the crop-selling households if they had not sold the crops. This term is not observed directly, and it is estimated for household $i$ using the following predicted expenditure:

$\hat{Y}_{i\left(D_{i}=0\right)} \mid D_{i}>0=Y_{i}-\hat{\gamma}_{i}$,

Where $\hat{\gamma}$ is estimated from equation (1). In case of equation (2), expenditure without crop revenues for the crop-selling households is predicted as follows: 


$$
\begin{aligned}
\hat{Y}_{i\left(D_{i}=0\right)} \mid D_{i}>0 & =e^{\ln \left(Y_{i(D=0)}\right)} \\
& =e^{\hat{\alpha}+X_{i} \hat{\beta}+\hat{\varepsilon}_{i}} \\
& =e^{\hat{\alpha}+X_{i} \hat{\beta}+D_{i} \hat{\gamma}+\hat{\varepsilon}_{i}-D_{i} \hat{\gamma}} \\
& =e^{\ln \left(Y_{i}\right)-D_{i} \hat{\gamma}} \\
& =Y_{i} e^{-D_{i} \hat{\gamma}}
\end{aligned}
$$

We can also measure the impact of crop sale on the total rural poverty as follows: $\Delta P=P(Y)-P\left(Y_{(D=0)}\right)$,

where $P(Y)$ is the observed poverty index of all rural population (in which the cropselling households had crop sales), and $P\left(Y_{(D=0)}\right)$ is the poverty index of all rural population if the crop-selling households had not received any money from the crop sales.

\section{EMPIRICAL RESULTS ON IMPACT MEASUREMENTS}

In order to measure the impact of cash crops, the models of per capita expenditure are estimated using VHLSSs 2002 and 2004. The explanatory variables include household composition, age of household head, education of head and head's spouse, land and housing characteristics, regional dummy variables, and commune characteristics. The list of explanatory variables is presented in table A.1 in Appendix. In order to control for inflation, we have deflated all variables in terms of 2004 prices. To examine the sensitivity of impact estimates to different models, we use eight Models (table A.2 in Appendix). Models from 1 to 4 use the linear function of expenditure, while Models from 5 to 8 use the semi-log linear function of expenditure. For the both outcome functions, there are four ways of estimation: fixed-effect and random-effect regressions using panel data from the 2002-2004 VHLSSs, OLS regression using the 2004 VHLSS, and instrumental variable (IV) regression using the 2004 VHLSS. For the instrumental variable regression, the instrumental variables used for the crop revenues in 2004 are the revenues of cash crops in 2002. Although the validity of these instrumental variables can be questionable, empirical studies often use treatment variables in the past as instruments for the current treatment variables (e.g., see Van de Walle, 2004).

The regression results reported in table A.2 (appendix) show that the estimates are stable across the models. The estimates of all the crop revenues are statistically significant in all the models. The R-squared is higher in the semi-log equations than in 
the linear function. The estimates of coefficients of crop sales are also more statistically significant in the semi-log equations.

Using the instrumental variable regression, we can test the endogeneity of crop sales. Results from Durbin-Wu-Hausman tests show that the hypothesis on the exogeneity of the crop sales is not rejected (table A.2 in Appendix). A problem in the instrumental variable regression is that the assumption on exclusion of the instruments in the outcome equations might not be valid, since the sales in 2002 (the instruments) can affect household expenditure in 2004. Regarding the random-effect and fixed-effect models, the Hausman statistic which tests the null hypothesis of no systematic difference in coefficient estimates between two models is equal to 67.2 (result not reported in the paper). Thus the null hypothesis is strongly rejected, and we incline to the fixed-effect model. In the following tables, only estimation results from Models 1 and 5 (i.e., fixedeffect regressions) are reported. The estimation results from other models are quite similar and not reported in this paper. ${ }^{6}$

Table 1 presents the estimates of APET for the cash crop sales. All the estimates are positive and statistically significant. For example, Model 5 shows that an increase of one VND in rice revenues leads to an increase of 0.019 VND in per capita expenditure. The corresponding figures for sales of annually crops, perennial crops, and fruits are $0.038,0.040$ and 0.036 respectively.

Table 1. Impact of crop revenues on per capita expenditure (APET)

\begin{tabular}{|c|c|c|}
\hline & Model 1 & Model 5 \\
\hline \multirow[t]{2}{*}{ Revenues of rice (thousand VND) } & $0.023^{*}$ & $0.019^{* *}$ \\
\hline & [0.013] & [0.008] \\
\hline \multirow[t]{2}{*}{ Revenues of other annual crops (thousand VND) } & $0.030^{* *}$ & $0.038^{* * *}$ \\
\hline & [0.013] & [0.013] \\
\hline \multirow[t]{2}{*}{ Revenues of perennial crops (thousand VND) } & $0.035^{\star \star *}$ & $0.040^{* * *}$ \\
\hline & [0.011] & [0.010] \\
\hline \multirow[t]{2}{*}{ Revenues of fruit (thousand VND) } & $0.039^{* * *}$ & $0.036^{* * *}$ \\
\hline & {$[0.015]$} & {$[0.013]$} \\
\hline \multicolumn{3}{|c|}{$\begin{array}{l}\text { Source: Estimation from VHLSSs } 2002-2004 \text {. } \\
\text { Note: }{ }^{*} \text { significant at } 10 \% ;{ }^{* *} \text { significant at } 5 \% ;{ }^{* \star *} \text { significant at } 1 \% \\
\text { Figures in parentheses are standard errors. Standard errors are corrected for } \\
\text { sampling weights and estimated using bootstrap (non-parametric) with } 200 \\
\text { replications. }\end{array}$} \\
\hline
\end{tabular}

Since the cash crops have increased household expenditure, they can reduce poverty of the crop-selling households. In this paper, a household is classified as poor if

\footnotetext{
${ }^{6}$ These results can be provided on request.
} 
their per capita expenditure is below the expenditure poverty line. ${ }^{7}$ Tables 2 through 5 present the impact estimates on poverty of sales from rice, annual crops, perennial crops and fruit.

In table 2, estimates from Model 1 are not statistically significant, while estimates from Model 5 are statistically significant at the 5 per cent level. According to Model 5, rice sales reduce the poverty incidence of the rice-growing households by around 1.4 percentage points. They also decrease the poverty gap and severity indexes by around 4.5 per cent. The effects on total poverty are smaller. Rice sales help reduce the poverty incidence of all rural households by around 0.6 percentage points, and decrease the rural poverty gap and severity indexes by around 2 per cent.

Table 2. Impact of rice sales on poverty

\begin{tabular}{|c|c|c|c|c|c|}
\hline \multirow[b]{2}{*}{ Index } & \multirow{2}{*}{$\begin{array}{l}\text { With crop } \\
\text { sales }\end{array}$} & \multicolumn{2}{|c|}{ Model 1} & \multicolumn{2}{|c|}{ Model 5} \\
\hline & & $\begin{array}{c}\text { Without crop } \\
\text { sales }\end{array}$ & Impact & $\begin{array}{c}\text { Without crop } \\
\text { sales }\end{array}$ & Impact \\
\hline \multicolumn{6}{|l|}{ Poverty of recipients } \\
\hline \multirow{2}{*}{$\overline{\text { Poverty incidence (P0) }}$} & $0.2534^{\star * *}$ & $0.2731^{* * *}$ & -0.0197 & $0.2671^{* * *}$ & $-0.0137^{* *}$ \\
\hline & {$[0.0144]$} & {$[0.0217]$} & {$[0.0176]$} & {$[0.0145]$} & [0.0070] \\
\hline \multirow[t]{2}{*}{ Poverty gap index (P1) } & $0.0630^{* * *}$ & $0.0713^{* * *}$ & -0.0083 & $0.0661^{* * *}$ & $-0.0031^{* *}$ \\
\hline & {$[0.0048]$} & {$[0.0080]$} & [0.0061] & {$[0.0050]$} & [0.0014] \\
\hline \multirow[t]{2}{*}{ Poverty severity index (P2) } & $0.0227^{\star * \star}$ & $0.0266^{* * *}$ & -0.0039 & $0.0238^{* * *}$ & $-0.0011^{* *}$ \\
\hline & [0.0023] & {$[0.0046]$} & [0.0037] & [0.0025] & [0.0005] \\
\hline \multicolumn{6}{|l|}{ Poverty of all rural } \\
\hline \multirow[t]{2}{*}{ Poverty incidence (P0) } & $0.2540^{\star * *}$ & $0.2624^{\star \star \star}$ & -0.0084 & $0.2598^{\star * *}$ & $-0.0059^{* *}$ \\
\hline & [0.0085] & [0.0118] & {$[0.0076]$} & [0.0090] & {$[0.0030]$} \\
\hline \multirow[t]{2}{*}{ Poverty gap index (P1) } & $0.0611^{* * *}$ & $0.0646^{* * *}$ & -0.0036 & $0.0624^{* * *}$ & $-0.0013^{\star *}$ \\
\hline & {$[0.0026]$} & [0.0039] & {$[0.0026]$} & {$[0.0030]$} & {$[0.0006]$} \\
\hline \multirow[t]{2}{*}{ Poverty severity index (P2) } & $0.0218^{\star * \star}$ & $0.0235^{\star * *}$ & -0.0017 & $0.0223^{\star * \star}$ & $-0.0005^{\star *}$ \\
\hline & [0.0012] & [0.0022] & [0.0016] & [0.0014] & [0.0002] \\
\hline \multicolumn{6}{|c|}{$\begin{array}{l}\text { Source: Estimation from VHLSSs } 2002-2004 . \\
\text { Note: }{ }^{*} \text { significant at } 10 \% ;{ }^{* *} \text { significant at } 5 \% ;{ }^{* * *} \text { significant at } 1 \% \\
\text { Figures in parentheses are standard errors. Standard errors are corrected for sampling weights and estimated using } \\
\text { bootstrap (non-parametric) with } 200 \text { replications. }\end{array}$} \\
\hline
\end{tabular}

Tables 3 and 4 present the impact estimates on poverty indexes of annual and perennial crop sales. All the estimates are statistically significant. Sales from annual and perennial crops reduce the poverty incidence of the crop-growing households by 2.6 (table 3) and 5.2 (table 4) percentage points (Model 5). They also decrease the poverty gap and severity indexes of the crop-growing households and rural households. The effect

\footnotetext{
${ }^{7}$ This poverty line is set up by WB and GSO. The poverty line is equivalent to the expenditure level that allows for nutritional needs and some essential non-food consumption such as clothing and housing. This poverty line was first estimated in 1993. Poverty lines in the following years are estimated by deflating the 1993 poverty line using the consumer price index. Thus the poverty lines are comparable overtime. The poverty lines in the years 1993, 1998, 2002, and 2004 are equal to 1160, 1790, 1917, and 2077 thousands VND, respectively.
} 
of perennial crops is higher than that of annual crops. They reduce the poverty gap and severity indexes of the perennial-crop-growing households by around 12 and 4 per cent (table 4), respectively.

Table 3. Impact of annual crop sales on poverty

\begin{tabular}{|c|c|c|c|c|c|}
\hline \multirow[b]{2}{*}{ Index } & \multirow{2}{*}{$\begin{array}{l}\text { With crop } \\
\text { sales }\end{array}$} & \multicolumn{2}{|c|}{ Model 1} & \multicolumn{2}{|c|}{ Model 5} \\
\hline & & $\begin{array}{l}\text { Without crop } \\
\text { sales }\end{array}$ & Impact & $\begin{array}{l}\text { Without crop } \\
\text { sales }\end{array}$ & Impact \\
\hline \multicolumn{6}{|l|}{ Poverty of recipients } \\
\hline \multirow[t]{2}{*}{ Poverty incidence (P0) } & $0.3102^{* * *}$ & $0.3394^{\star * *}$ & $-0.0292^{\star \star *}$ & $0.3364^{* * *}$ & $-0.0262^{\star \star \star}$ \\
\hline & [0.0157] & {$[0.0177]$} & [0.0094] & [0.0149] & [0.0077] \\
\hline \multirow[t]{2}{*}{ Poverty gap index (P1) } & $0.0823^{\star * *}$ & $0.0941^{* * *}$ & $-0.0118^{* *}$ & $0.0889^{* * *}$ & $-0.0065^{\star * *}$ \\
\hline & [0.0053] & {$[0.0075]$} & {$[0.0048]$} & [0.0053] & [0.0022] \\
\hline \multirow[t]{2}{*}{ Poverty severity index (P2) } & $0.0315^{\star * *}$ & $0.0381^{* * *}$ & $-0.0066^{* *}$ & $0.0342^{* * *}$ & $-0.0027^{* *}$ \\
\hline & [0.0028] & [0.0046] & {$[0.0034]$} & {$[0.0028]$} & [0.0010] \\
\hline \multicolumn{6}{|l|}{ Poverty of all rural } \\
\hline \multirow[t]{2}{*}{ Poverty incidence (P0) } & $0.2540^{\star * \star}$ & $0.2649^{\star \star \star}$ & $-0.0109^{\star *}$ & $0.2638^{\star * \star}$ & $-0.0098^{\star \star *}$ \\
\hline & {$[0.0085]$} & [0.0102] & {$[0.0036]$} & {$[0.0087]$} & [0.0029] \\
\hline \multirow[t]{2}{*}{ Poverty gap index (P1) } & $0.0611^{* * *}$ & $0.0655^{\star \star *}$ & $-0.0044^{* *}$ & $0.0635^{\star \star *}$ & $-0.0025^{\star * *}$ \\
\hline & {$[0.0026]$} & [0.0038] & {$[0.0018]$} & {$[0.0027]$} & [0.0008] \\
\hline \multirow[t]{2}{*}{ Poverty severity index (P2) } & $0.0218^{\star * \star}$ & $0.0243^{\star \star *}$ & $-0.0025^{\star *}$ & $0.0228^{\star \star \star}$ & $-0.0010^{* *}$ \\
\hline & {$[0.0012]$} & {$[0.0021]$} & [0.0013] & [0.0013] & [0.0004] \\
\hline
\end{tabular}

Source: Estimation from VHLSSs 2002-2004.

Note: ${ }^{*}$ significant at $10 \% ;{ }^{* *}$ significant at $5 \%$; ${ }^{* * *}$ significant at $1 \%$

Figures in parentheses are standard errors. Standard errors are corrected for sampling weights and estimated using bootstrap (non-parametric) with 200 replications.

Table 4. Impact of perennial crop sales on poverty

\begin{tabular}{|c|c|c|c|c|c|}
\hline \multirow[b]{2}{*}{ Index } & \multirow{2}{*}{$\begin{array}{l}\text { With crop } \\
\text { sales }\end{array}$} & \multicolumn{2}{|c|}{ Model 1} & \multicolumn{2}{|c|}{ Model 5} \\
\hline & & $\begin{array}{l}\text { Without crop } \\
\text { sales }\end{array}$ & Impact & $\begin{array}{l}\text { Without crop } \\
\text { sales }\end{array}$ & Impact \\
\hline \multicolumn{6}{|l|}{$\underline{\text { Poverty of recipients }}$} \\
\hline Poverty incidence (P0) & $\begin{array}{c}0.3370^{* * *} \\
{[0.0222]}\end{array}$ & $\begin{array}{r}0.4087^{\star * *} \\
{[0.0287]}\end{array}$ & $\begin{array}{r}-0.0717^{* * *} \\
{[0.0202]}\end{array}$ & $\begin{array}{r}0.3889^{* * *} \\
{[0.0268]}\end{array}$ & $\begin{array}{r}-0.0520^{* * *} \\
{[0.0153]}\end{array}$ \\
\hline Poverty gap index (P1) & $\begin{array}{r}0.0795^{\star * *} \\
{[0.0069]}\end{array}$ & $\begin{array}{r}0.1103^{* * *} \\
{[0.0185]}\end{array}$ & $\begin{array}{r}-0.0308^{* *} \\
{[0.0160]}\end{array}$ & $\begin{array}{r}0.0912^{* * *} \\
{[0.0088]}\end{array}$ & $\begin{array}{r}-0.0117^{* * *} \\
{[0.0043]}\end{array}$ \\
\hline Poverty severity index (P2) & $\begin{array}{c}0.0271^{* * *} \\
{[0.0031]}\end{array}$ & $\begin{array}{c}0.0431^{* * *} \\
{[0.0178]}\end{array}$ & $\begin{array}{r}-0.0160 \\
{[0.0172]}\end{array}$ & $\begin{array}{c}0.0314^{* * *} \\
{[0.0039]}\end{array}$ & $\begin{array}{r}-0.0042^{\star *} \\
{[0.0018]}\end{array}$ \\
\hline Poverty of all rural & & & & & \\
\hline Poverty incidence (P0) & $\begin{array}{c}0.2540^{* * *} \\
{[0.0085]}\end{array}$ & $\begin{array}{c}0.2676^{\star * *} \\
{[0.0094]}\end{array}$ & $\begin{array}{r}-0.0136^{* * *} \\
{[0.0039]}\end{array}$ & $\begin{array}{c}0.2638^{* * *} \\
{[0.0091]}\end{array}$ & $\begin{array}{r}-0.0099^{* * *} \\
{[0.0029]}\end{array}$ \\
\hline Poverty gap index (P1) & $\begin{array}{c}0.0611^{* * *} \\
{[0.0026]}\end{array}$ & $\begin{array}{c}0.0669^{* * *} \\
{[0.0044]}\end{array}$ & $\begin{array}{c}-0.0058^{* *} \\
{[0.0032]}\end{array}$ & $\begin{array}{c}0.0633^{* * *} \\
{[0.0030]}\end{array}$ & $\begin{array}{r}-0.0022^{* * *} \\
{[0.0008}\end{array}$ \\
\hline Poverty severity index (P2) & $\begin{array}{r}0.0218^{\star * *} \\
{[0.0012]}\end{array}$ & $\begin{array}{r}0.0249^{\star * *} \\
{[0.0037]}\end{array}$ & $\begin{array}{r}-0.0030 \\
{[0.0033]}\end{array}$ & $\begin{array}{r}0.0226^{\star * *} \\
{[0.0015]}\end{array}$ & $\begin{array}{r}-0.0008^{* * *} \\
{[0.0003]}\end{array}$ \\
\hline
\end{tabular}

Source: Estimation from VHLSSs 2002-2004.

Note: ${ }^{*}$ significant at $10 \% ;{ }^{* *}$ significant at $5 \% ;{ }^{* * *}$ significant at $1 \%$

Figures in parentheses are standard errors. Standard errors are corrected for sampling weights and estimated using bootstrap (non-parametric) with 200 replications. 
Finally, table 5 reports impact estimates of fruit sales. Fruit sales decrease the poverty rate of the growing households by around 1.1 percentage points (Model 5). The estimated effect on the poverty rate of rural households is quite small, at 0.4 percentage point. Regarding to poverty gap and severity, most of the estimates are not statistically significant. This might be because the poverty gap and indexes of the fruit-growing households are smaller than households with other crops.

Table 5. Impact of fruit sales on poverty

\begin{tabular}{|c|c|c|c|c|c|}
\hline \multirow[b]{2}{*}{ Index } & \multirow{2}{*}{$\begin{array}{l}\text { With crop } \\
\text { sales }\end{array}$} & \multicolumn{2}{|c|}{ Model 1} & \multicolumn{2}{|c|}{ Model 5} \\
\hline & & $\begin{array}{c}\text { Without crop } \\
\text { sales }\end{array}$ & Impact & $\begin{array}{l}\text { Without crop } \\
\text { sales }\end{array}$ & Impact \\
\hline \multicolumn{6}{|l|}{ Poverty of recipients } \\
\hline \multirow[t]{2}{*}{ Poverty incidence (P0) } & $0.2162^{\star * *}$ & $0.2373^{\star * *}$ & $-0.0210^{* *}$ & $0.2267^{* \star *}$ & $-0.0105^{\star *}$ \\
\hline & {$[0.0120]$} & {$[0.0158]$} & {$[0.0095]$} & {$[0.0153]$} & [0.0051] \\
\hline \multirow[t]{2}{*}{ Poverty gap index (P1) } & $0.0475^{\star * *}$ & $0.0525^{\star * *}$ & -0.0049 & $0.0499^{* * *}$ & $-0.0023^{\star *}$ \\
\hline & [0.0039] & {$[0.0057]$} & {$[0.0039]$} & {$[0.0047]$} & [0.0009] \\
\hline \multirow[t]{2}{*}{ Poverty severity index (P2) } & $0.0163^{\star \star \star}$ & $0.0185^{\star * *}$ & -0.0021 & $0.0167^{* * *}$ & -0.0003 \\
\hline & {$[0.0020]$} & {$[0.0044]$} & [0.0039] & [0.0023] & [0.0003] \\
\hline \multicolumn{6}{|l|}{ Poverty of all rural } \\
\hline \multirow[t]{2}{*}{ Poverty incidence (P0) } & $0.2540^{* * *}$ & $0.2615^{\star \star \star}$ & $-0.0076^{* *}$ & $0.2580^{* * *}$ & $-0.0041^{* *}$ \\
\hline & {$[0.0076]$} & [0.0088] & {$[0.0034]$} & {$[0.0090]$} & [0.0018] \\
\hline \multirow[t]{2}{*}{ Poverty gap index (P1) } & $0.0611^{* * *}$ & $0.0628^{* * *}$ & -0.0018 & $0.0615^{\star * *}$ & -0.0005 \\
\hline & [0.0027] & [0.0032] & {$[0.0014]$} & [0.0028] & [0.0003] \\
\hline \multirow[t]{2}{*}{ Poverty severity index (P2) } & $0.0218^{* * *}$ & $0.0226^{* * *}$ & -0.0008 & $0.0219^{* * *}$ & -0.0001 \\
\hline & [0.0013] & {$[0.0020]$} & {$[0.0014]$} & [0.0013] & {$[0.0001]$} \\
\hline $\begin{array}{l}\text { Source: Estimation from VI } \\
\text { Note: * significant at } 10 \% \text {; } \\
\text { Figures in parentheses are } \\
\text { bootstrap (non-parametric) }\end{array}$ & $\begin{array}{l}02-2004 . \\
\text { ant at } 5 \% ; * * \\
\text { errors. Stan }\end{array}$ & $\begin{array}{l}\text { nificant at } 1 \% \\
\text { errors are co }\end{array}$ & forc & eiahts an & usir \\
\hline
\end{tabular}

It should be noted that we measure the impact of cash crop revenues on expenditure and poverty by comparing expenditure and poverty in the presence of the crop revenues and counterfactual expenditure and poverty in the absence of the crop revenues. We do not compare expenditure and poverty between crop households and noncrop households. Although, households with crops tend to have lower expenditure and higher poverty than households without crops, crop revenues still play an important role in increasing expenditure and reducing poverty for the crop-growing households. This is because crop revenues are still a main important revenue source for the crop-growing households. 


\section{CONCLUSION}

Vietnam is a developing country with a large proportion of population involved in agricultural activities. Although crop production is often mentioned as an important activity for economic growth and poverty reduction, there are only a few studies measuring quantitative impacts of crop production on poverty reduction. This paper is the first study which uses nationally representative household surveys in order to measure impacts of the cash crop sales on household consumption expenditure and poverty in Vietnam.

It is found that revenues from cash crops have positive and statistically significant impacts on per capita expenditure of the crop-selling households. More specifically, an increase of one VND in rice revenues leads to an increase of 0.019 VND in per capita expenditure, and the corresponding figures for sales of annually crops, perennial crops, and fruits are $0.038,0.040$ and 0.036 , respectively. As a result, the crop sales help reduce poverty of the crop-growing households and rural population. Among the crops, perennial crops have largest effect on poverty reduction in terms of point estimates. They decrease the poverty incidence of the crop-growing households by around 5.2 percentage points. They reduce the poverty gap and severity indexes of the perennial-crop-growing households by around 12 per cent. The fruit crop sales have small point estimates of impacts on poverty. They decrease the poverty rate of the growing households and all rural household by around 1.1 and 0.4 percentage points, respectively.

The findings might suggest several policy implications for crop production in Vietnam. Firstly, non-farm production can be an important activity to increasing income, expenditure and reducing poverty. Descriptive data analysis shows that households with crops tend to have lower expenditure and higher poverty than households without crops. Secondly, cash crops still have an important role in poverty reduction, and the government should have measures and policies to increase the crop revenues of farm households. The findings also show that the perennial crops have higher effect on poverty reduction than other crops. Thus, promotion of perennial crops can result in remarkable reduction of rural poverty. 


\section{REFERENCES}

Easterly, W. and A. Kraay (2000). "Small states, small problems? Income, growth, and volatility in small states", World Development, vol. 28, No. 11, p. 2013-27.

Foster, J., J. Greer, E. Thorbecke (1984). “A class of decomposable poverty measures”, Econometrica, vol. 52, p. 761-765.

Harrison, A. (2005). Globalization and Poverty (National Bureau of Economic Research Conference Report, edited by Harrison Anne, Chicago University Press).

Irz, X, Lin Lin, Thirtle C. and Wiggins, S. (2001). "Agricultural productivity growth and poverty alleviation", Development Policy Review, vol. 19, No. 4, p. 449-466.

Johnston, B.F. and Mellor, J.W. (1961). "The role of agriculture in economic development", American Economic Review, Vol. 51, p. 566-93.

Lanjouw, J. O. and P. Lanjouw (1995). "Rural nonfarm employment: a survey", Policy Research Working Paper, No. 1463. The World Bank.

Lanjouw, P. (1998). "Ecuador's rural nonfarm sector as a route out of poverty”, Policy Research Working Paper, No. 1094. The World Bank.

Levy, S. and van Wijnbergen S. (1992). "Agricultural adjustment and the Mexico - USA free trade agreement", Chapter 3 of Goldin I and Winters L. A. (eds) Open Economies: Structural Adjustment and Agriculture (Cambridge University Press, Cambridge), p. 4262.

McCulloch, N., L. A. Winters and X Cirera (2001). Trade Liberalization and Poverty: A Handbook. London (Centre for Economic Policy Research).

Nadal, A. (2000). The Environmental and Social Impacts of Economic Liberalization on Corn Production in Mexico (Oxfam GB, and WWF International).

Ranis, G., Stewart, F. and Angeles-Reyes, E. (1990). Linkages in Developing Countries: A Philippine Study, ICS Press for International Center for Economic Growth (San Francisco, CA).

Ruerd, R. and M. van den Berg (2001). "Nonfarm employment and poverty alleviation of rural farm households in Honduras”, World Development, vol. 29, No. 3, p. 549-560.

Thorbecke, E. and H. Jung (1996). "A multiplier decomposition method to analyze poverty alleviation", Journal of Development Economics, vol. 48, p. 279-300. 
Timmer, C.P. (2002). "Agriculture and economic development”, in B. Gardner and G. Rausser eds., Handbook of Agricultural Economics, vol. 2 (Elsevier Science B.V).

Van de Walle, D. (1994). "Rural poverty in an emerging market economy: is diversification into nonfarm activities in rural Viet Nam the solution?", Policy Research Department, The World Bank, Unpublished manuscript.

Van de Walle, D. (2004). “Testing Viet Nam's public safety net”, Journal of Comparative Economics, vol. 32, No.4, p. 661-679.

Winters, A., N. McCulloch, and A. McKay (2004). "Trade liberalization and poverty: the evidence so far", Journal of Economic Literature, vol. XLII, p. 72-115.

Wooldridge J. M. (2001). Econometric Analysis of Cross Section and Panel Data (The MIT Press, Cambridge, Massachusetts London, England).

World Bank (2004). Viet Nam Development Report: Poverty (World Bank in Viet Nam). 


\section{APPENDIX}

Table A.1. Variable description

\begin{tabular}{|c|c|c|c|c|c|}
\hline \multirow{2}{*}{ Variables } & \multirow{2}{*}{ Type } & \multicolumn{2}{|c|}{2002} & \multicolumn{2}{|c|}{2004} \\
\hline & & Mean & Std. Dev. & Mean & Std. Dev. \\
\hline Per capita expenditure (thousand VND)* & Continuous & 2839.6 & 40.1 & 3340.4 & 46.0 \\
\hline \multicolumn{6}{|l|}{ Variables of crop sales } \\
\hline Revenues of rice (thousand VND)* & Continuous & 2330.3 & 214.1 & 2687.7 & 207.1 \\
\hline Revenues of annual crops (thousand VND)* & Continuous & 604.4 & 56.4 & 984.6 & 91.1 \\
\hline Revenues of perennial crops (thousand VND)* & Continuous & 848.6 & 158.9 & 1295.0 & 220.2 \\
\hline Revenues of fruit (thousand VND) ${ }^{*}$ & Continuous & 855.4 & 107.9 & 898.0 & 100.9 \\
\hline \multicolumn{6}{|l|}{ Household variables } \\
\hline Ratio of members less than 16 & Continuous & 0.305 & 0.005 & 0.280 & 0.004 \\
\hline Ratio of members older than 60 & Continuous & 0.089 & 0.003 & 0.095 & 0.003 \\
\hline Age of household head & Discrete & 47.0 & 0.3 & 48.4 & 0.3 \\
\hline Household size & Discrete & 5.061 & 0.044 & 5.133 & 0.049 \\
\hline Head with less than primary school & Binary & 0.341 & 0.011 & 0.316 & 0.011 \\
\hline Head with primary school & Binary & 0.260 & 0.009 & 0.264 & 0.009 \\
\hline Head with lower secondary school & Binary & 0.282 & 0.011 & 0.278 & 0.010 \\
\hline Head with upper secondary school & Binary & 0.070 & 0.005 & 0.055 & 0.005 \\
\hline Head with technical degree & Binary & 0.036 & 0.004 & 0.070 & 0.005 \\
\hline Head with post secondary school & Binary & 0.011 & 0.002 & 0.017 & 0.003 \\
\hline Head no spouse & Binary & 0.137 & 0.007 & 0.140 & 0.007 \\
\hline Head's spouse with less than primary school & Binary & 0.334 & 0.012 & 0.323 & 0.011 \\
\hline Head's spouse with primary school & Binary & 0.228 & 0.009 & 0.229 & 0.009 \\
\hline Head's spouse with lower secondary school & Binary & 0.231 & 0.010 & 0.224 & 0.010 \\
\hline Head's spouse with upper secondary school & Binary & 0.043 & 0.004 & 0.037 & 0.004 \\
\hline Head's spouse with technical degree & Binary & 0.017 & 0.003 & 0.036 & 0.004 \\
\hline Head's spouse with post secondary school & Binary & 0.010 & 0.002 & 0.010 & 0.002 \\
\hline Log of living areas (log of m2) & Continuous & 3.902 & 0.012 & 3.981 & 0.012 \\
\hline Living in permanent house & Binary & 0.117 & 0.008 & 0.136 & 0.008 \\
\hline Living in semi-permanent house & Binary & 0.603 & 0.012 & 0.624 & 0.011 \\
\hline Living in temporary house & Binary & 0.279 & 0.011 & 0.239 & 0.011 \\
\hline Area of annual crop land (m2) & Continuous & 4305.1 & 203.5 & 4374.7 & 195.6 \\
\hline Area of perennial crop land (m2) & Continuous & 1532.7 & 141.5 & 1248.8 & 139.5 \\
\hline Area of forestry land (m2) & Continuous & 1666.1 & 296.9 & 1144.8 & 191.8 \\
\hline Area of aquaculture water surface (m2) & Continuous & 399.7 & 84.7 & 316.6 & 70.1 \\
\hline \multicolumn{6}{|l|}{ Commune variables } \\
\hline Having non-farm enterprise in commune & Binary & 0.979 & 0.005 & 0.841 & 0.012 \\
\hline Distance to nearest town $(\mathrm{km})$ & Continuous & 8.785 & 0.283 & 9.158 & 0.309 \\
\hline Distance to nearest road $(\mathrm{km})$ & Continuous & 0.684 & 0.099 & 0.594 & 0.099 \\
\hline Distance to nearest daily market $(\mathrm{km})$ & Continuous & 2.795 & 0.184 & 3.087 & 0.187 \\
\hline Distance to nearest periodic market $(\mathrm{km})$ & Continuous & 3.560 & 0.233 & 2.052 & 0.140 \\
\hline Distance to nearest post $(\mathrm{km})$ & Continuous & 3.091 & 0.192 & 2.361 & 0.152 \\
\hline \multicolumn{6}{|l|}{ Dummy regional variables } \\
\hline Red River Delta & Binary & 0.201 & 0.013 & 0.201 & 0.013 \\
\hline North East & Binary & 0.129 & 0.010 & 0.129 & 0.010 \\
\hline North West & Binary & 0.031 & 0.005 & 0.031 & 0.005 \\
\hline North Central Coast & Binary & 0.152 & 0.013 & 0.152 & 0.013 \\
\hline South Central Coast & Binary & 0.089 & 0.009 & 0.089 & 0.009 \\
\hline Central Highlands & Binary & 0.063 & 0.008 & 0.063 & 0.008 \\
\hline
\end{tabular}




\begin{tabular}{lrrrrr}
\hline \hline \multirow{2}{*}{ Variables } & \multirow{2}{*}{ Type } & \multicolumn{2}{c}{2002} & \multicolumn{2}{c}{2004} \\
\cline { 4 - 6 } & & Mean & Std. Dev. & Mean & Std. Dev. \\
\hline North East South & Binary & 0.094 & 0.009 & 0.094 & 0.009 \\
Mekong River Delta & Binary & 0.242 & 0.014 & 0.242 & 0.014 \\
\hline Number of observations & & 3099 & & 3099 \\
\hline
\end{tabular}

Source: Estimation from VHLSSs 2002 and 2004.

Note: * in 2004 price. 
Table A.2. Regression results

\begin{tabular}{|c|c|c|c|c|c|c|c|c|}
\hline \multirow[b]{2}{*}{ Explanatory variables } & \multicolumn{4}{|c|}{ Dependent variable: Per capita expenditure } & \multicolumn{4}{|c|}{ Dependent variable: Logarithm of per capita expenditure } \\
\hline & $\begin{array}{c}\text { Model 1: } \\
\text { Fixed-effect }\end{array}$ & $\begin{array}{c}\text { Model 2: } \\
\text { Random } \\
\text { effect }\end{array}$ & $\begin{array}{l}\text { Model 3: } \\
\text { OLS }\end{array}$ & $\begin{array}{l}\text { Model 4: } \\
\text { IV }\end{array}$ & $\begin{array}{l}\text { Model 5: } \\
\text { Fixed-effect }\end{array}$ & $\begin{array}{c}\text { Model 6: } \\
\text { Random effect }\end{array}$ & $\begin{array}{l}\text { Model 7: } \\
\text { OLS }\end{array}$ & $\begin{array}{l}\text { Model 8: } \\
\text { IV }\end{array}$ \\
\hline \multirow[t]{2}{*}{ Revenues of rice } & $0.023^{*}$ & $0.031^{* * *}$ & $0.034^{\star \star *}$ & $0.030^{\star * *}$ & $0.0000043^{\star *}$ & $0.0000088^{* \star *}$ & $0.0000083^{\star \star \star}$ & $0.0000093^{\star \star \star}$ \\
\hline & [0.013] & {$[0.007]$} & [0.009] & {$[0.010]$} & {$[0.0000020]$} & [0.0000012] & [0.0000012] & [0.0000019] \\
\hline \multirow[t]{2}{*}{ Revenues of annual crops } & $0.030^{\star *}$ & $0.023^{\star \star *}$ & $0.018^{\star *}$ & $0.025^{\star}$ & $0.0000102^{\star \star \star}$ & $0.0000091^{\star * *}$ & $0.0000074^{\star * *}$ & $0.0000103^{* *}$ \\
\hline & [0.013] & [0.008] & {$[0.008]$} & {$[0.015]$} & {$[0.0000031]$} & [0.0000022] & [0.0000021] & {$[0.0000046]$} \\
\hline \multirow[t]{2}{*}{ Revenues of perennial crops } & $0.035^{* * *}$ & $0.023^{* * *}$ & $0.020^{* * *}$ & $0.024^{* * *}$ & $0.0000086^{* * *}$ & $0.0000055^{* * *}$ & $0.0000044^{* * *}$ & $0.0000051^{* * *}$ \\
\hline & {$[0.011]$} & [0.003] & [0.005] & [0.007] & {$[0.0000021]$} & [0.0000008] & {$[0.0000010]$} & {$[0.0000015]$} \\
\hline \multirow[t]{2}{*}{ Revenues of fruit } & $0.039^{* * *}$ & $0.040^{\star * *}$ & $0.036^{\star * *}$ & $0.035^{\star * *}$ & $0.0000093^{* * *}$ & $0.0000116^{* * *}$ & $0.0000097^{* * *}$ & $0.0000106^{* * *}$ \\
\hline & {$[0.015]$} & {$[0.010]$} & [0.011] & [0.013] & [0.0000024] & [0.0000018] & [0.0000019] & [0.0000030] \\
\hline \multirow[t]{2}{*}{ Ratio of members younger than 16} & $-1261.4^{\star \star \star}$ & $-1720.9^{\star * *}$ & $-2001.0^{* * *}$ & $-1995.7^{\star \star *}$ & $-0.35524^{* * *}$ & $-0.50076^{\star \star *}$ & $-0.55623^{\star \star \star}$ & $-0.55494^{\star * *}$ \\
\hline & [277.9] & [150.4] & [190.3] & [189.0] & [0.06152] & [0.03625] & [0.04579] & [0.04559] \\
\hline \multirow[t]{2}{*}{ Ratio of members who older than 60} & $-1225.4^{\star \star \star}$ & $-1104.0^{\star \star \star}$ & $-1063.6^{\star \star \star}$ & $-1080.8^{\star * *}$ & $-0.27818^{\star * \star}$ & $-0.28503^{\star * *}$ & $-0.26653^{* * *}$ & $-0.26530^{* * *}$ \\
\hline & [340.9] & [176.8] & [231.8] & [232.0] & [0.07231] & [0.03923] & [0.04931] & [0.04929] \\
\hline \multirow[t]{2}{*}{ Head age } & $67.319^{\star *}$ & -0.669 & -2.76 & -2.534 & $0.02319^{\star * *}$ & 0.00523 & -0.00001 & -0.00015 \\
\hline & [31.319] & [14.067] & [15.835] & [15.663] & {$[0.00793]$} & [0.00381] & [0.00424] & [0.00422] \\
\hline \multirow[t]{2}{*}{ Head age squared } & $-0.505^{\star}$ & 0.085 & 0.081 & 0.083 & $-0.00018^{* *}$ & -0.00002 & 0.00002 & 0.00002 \\
\hline & [0.303] & {$[0.136]$} & {$[0.149]$} & {$[0.147]$} & [0.00008] & {$[0.00004]$} & [0.00004] & {$[0.00004]$} \\
\hline \multirow[t]{2}{*}{ Household size } & $-813.307^{* * *}$ & $-562.218^{* \star \star}$ & $-592.555^{\star * *}$ & $-594.747^{\star \star \star}$ & $-0.18473^{* * *}$ & $-0.13634^{\star \star \star}$ & $-0.12364^{\star * *}$ & $-0.12426^{\star \star \star}$ \\
\hline & [109.723] & [63.408] & [78.441] & [78.030] & [0.02271] & [0.01324] & [0.01602] & [0.01596] \\
\hline \multirow[t]{2}{*}{ Household size squared } & $45.758^{* \star *}$ & $25.554^{\star \star *}$ & $24.996^{* * *}$ & $24.915^{\star * *}$ & $0.00860^{\star * *}$ & $0.00464^{\star \star *}$ & $0.00323^{\star *}$ & $0.00329^{* *}$ \\
\hline & [8.430] & [5.146] & [6.043] & [5.973] & [0.00187] & {$[0.00111]$} & {$[0.00134]$} & [0.00133] \\
\hline Head with less than primary school & Omitted & & & & & & & \\
\hline \multirow[t]{2}{*}{ Head with primary school } & $199.253^{*}$ & $254.947^{\star \star \star}$ & $253.845^{\star \star \star}$ & $252.004^{\star \star *}$ & $0.04643^{\star *}$ & $0.08811^{* \star *}$ & $0.09348^{\star \star \star}$ & $0.09457^{\star \star \star}$ \\
\hline & {$[110.781]$} & [62.640] & [94.990] & [94.831] & {$[0.02357]$} & {$[0.01557]$} & {$[0.02178]$} & {$[0.02175]$} \\
\hline \multirow[t]{2}{*}{ Head with lower secondary school } & $299.179^{\star \star}$ & $404.695^{\star \star \star}$ & $547.563^{\star \star *}$ & $547.180^{\star \star *}$ & $0.08099^{* *}$ & $0.12412^{\star \star *}$ & $0.15533^{\star \star \star}$ & $0.15729^{* \star *}$ \\
\hline & [149.047] & [76.227] & [113.818] & [113.283] & [0.03273] & {$[0.01858]$} & [0.02491] & [0.02493] \\
\hline \multirow[t]{2}{*}{ Head with upper secondary school } & 260.563 & $518.121^{\star * *}$ & $475.746^{\star * *}$ & $476.868^{\star * *}$ & $0.12790^{\star * *}$ & $0.18150^{* * *}$ & $0.16949^{* * *}$ & $0.17103^{* * *}$ \\
\hline & [253.859] & [114.893] & [148.381] & [147.202] & [0.04928] & {$[0.02898]$} & {$[0.03606]$} & {$[0.03570]$} \\
\hline \multirow[t]{2}{*}{ Head with technical degree } & $881.8^{* \star \star}$ & $1073.54^{\star * *}$ & $1061.94^{\star \star *}$ & $1062.55^{\star * *}$ & $0.23388^{\star * *}$ & $0.29430^{* * *}$ & $0.29453^{* * *}$ & $0.29786^{\star * *}$ \\
\hline & [207.90] & [141.93] & [180.17] & [179.03] & {$[0.04200]$} & [0.02882] & {$[0.03740]$} & [0.03729] \\
\hline \multirow[t]{2}{*}{ Head with post secondary school } & $1055.29^{\star \star}$ & $1735.88^{\star \star \star}$ & $1873.94^{\star \star \star}$ & $1874.67^{\star * \star}$ & $0.26970^{\star \star \star}$ & $0.43397^{\star \star *}$ & $0.46631^{* \star *}$ & $0.46988^{\star * \star}$ \\
\hline & {$[490.660]$} & [280.295] & {$[314.350]$} & [313.048] & [0.07819] & {$[0.04646]$} & {$[0.05257]$} & {$[0.05234]$} \\
\hline Head no spouse & Omitted & & & & & & & \\
\hline
\end{tabular}




\begin{tabular}{|c|c|c|c|c|c|c|c|c|}
\hline \multirow[b]{2}{*}{ Explanatory variables } & \multicolumn{4}{|c|}{ Dependent variable: Per capita expenditure } & \multicolumn{4}{|c|}{ Dependent variable: Logarithm of per capita expenditure } \\
\hline & $\begin{array}{c}\text { Model 1: } \\
\text { Fixed-effect }\end{array}$ & $\begin{array}{c}\text { Model 2: } \\
\text { Random } \\
\text { effect }\end{array}$ & $\begin{array}{l}\text { Model 3: } \\
\text { OLS }\end{array}$ & $\begin{array}{l}\text { Model 4: } \\
\text { IV }\end{array}$ & $\begin{array}{l}\text { Model 5: } \\
\text { Fixed-effect }\end{array}$ & $\begin{array}{c}\text { Model 6: } \\
\text { Random effect }\end{array}$ & $\begin{array}{l}\text { Model 7: } \\
\text { OLS }\end{array}$ & $\begin{array}{l}\text { Model 8: } \\
\text { IV }\end{array}$ \\
\hline \multirow{2}{*}{$\begin{array}{l}\text { Head's spouse with less than primary } \\
\text { school }\end{array}$} & $-386.828^{*}$ & $-312.130^{\star \star *}$ & $-313.697^{* * *}$ & $-310.602^{* * *}$ & -0.05797 & $-0.08579^{* * *}$ & $-0.09113^{\star \star *}$ & $-0.09265^{\star * *}$ \\
\hline & [221.162] & [88.222] & {$[115.865]$} & [114.872] & {$[0.04497]$} & [0.02102] & [0.02535] & [0.02533] \\
\hline \multirow[t]{2}{*}{ Head's spouse with primary school } & -366.332 & -152.198 & -107.205 & -104.212 & -0.03685 & -0.01672 & -0.00898 & -0.01201 \\
\hline & [234.085] & [101.092] & [132.681] & [131.098] & [0.04565] & [0.02317] & {$[0.02840]$} & [0.02850] \\
\hline \multirow{2}{*}{$\begin{array}{l}\text { Head's spouse with lower secondary } \\
\text { school }\end{array}$} & -325.632 & $-362.411^{\star \star \star}$ & $-510.096^{\star \star *}$ & $-512.178^{\star * *}$ & -0.01596 & $-0.05061^{* *}$ & $-0.09259^{\star \star \star}$ & $-0.09412^{* * *}$ \\
\hline & [240.926] & [106.936] & [144.959] & {$[143.424]$} & [0.04947] & {$[0.02420]$} & {$[0.03048]$} & {$[0.03032]$} \\
\hline \multirow[t]{2}{*}{$\begin{array}{l}\text { Head's spouse with upper secondary } \\
\text { school }\end{array}$} & -285.121 & 126.614 & 81.632 & 86.872 & 0.00537 & 0.06202 & 0.03807 & 0.03667 \\
\hline & [379.955] & [172.244] & [253.240] & [251.963] & {$[0.07318]$} & {$[0.03805]$} & {$[0.05078]$} & [0.05057] \\
\hline \multirow[t]{2}{*}{ Head's spouse with technical degree } & 572.955 & $884.202^{\star * \star}$ & $715.544^{* *}$ & $713.291^{* *}$ & $0.13973^{* *}$ & $0.19583^{* \star *}$ & $0.16427^{\star \star *}$ & $0.16285^{\star \star *}$ \\
\hline & [418.545] & [310.969] & [313.438] & [312.271] & {$[0.06998]$} & {$[0.04105]$} & [0.04549] & {$[0.04530]$} \\
\hline \multirow[t]{2}{*}{ Head's spouse with post secondary school } & 593.67 & $1200.40^{\star * *}$ & $1327.12^{\star \star *}$ & $1326.61^{* * *}$ & $0.20749^{\star *}$ & $0.28664^{* * *}$ & $0.27745^{\star \star *}$ & $0.27808^{* * *}$ \\
\hline & {$[595.691]$} & [348.851] & [424.874] & [422.373] & {$[0.09514]$} & [0.05953] & {$[0.06711]$} & {$[0.06690]$} \\
\hline \multirow[t]{2}{*}{ Log of living areas (log of m2) } & $368.599^{\star \star *}$ & $751.248^{\star * \star}$ & $968.838^{* * *}$ & $975.854^{* * *}$ & $0.08287^{\star * *}$ & $0.18655^{\star * \star}$ & $0.24961^{* * *}$ & $0.24795^{\star * *}$ \\
\hline & [82.784] & [68.084] & {$[104.766]$} & [105.512] & {$[0.01780]$} & {$[0.01596]$} & [0.02289] & [0.02281] \\
\hline \multirow[t]{2}{*}{ Living in permanent house } & $705.865^{\star \star \star}$ & $742.172^{\star * \star}$ & $780.790^{\star * *}$ & $775.023^{\star \star *}$ & $0.16731^{* * *}$ & $0.20322^{\star * *}$ & $0.20782^{\star * \star}$ & $0.20724^{\star \star *}$ \\
\hline & [156.135] & {$[100.190]$} & [143.871] & [143.318] & {$[0.03104]$} & {$[0.02181]$} & {$[0.03048]$} & [0.03036] \\
\hline \multirow[t]{2}{*}{ Living in semi-permanent house } & $192.595^{\star *}$ & $248.010^{\star * *}$ & $237.497^{\star * *}$ & $233.312^{* * *}$ & $0.06663^{* * *}$ & $0.09793^{* * *}$ & $0.09949^{* * *}$ & $0.09935^{* * *}$ \\
\hline & [78.723] & [48.789] & [79.680] & [79.565] & [0.01873] & {$[0.01396]$} & [0.02086] & [0.02082] \\
\hline Living in temporary house & Omitted & & & & & & & \\
\hline \multirow[t]{2}{*}{ Area of annual crop land (m2) } & 0.006 & -0.004 & 0.004 & 0.006 & 0.0000022 & -0.0000012 & 0.0000011 & 0.0000002 \\
\hline & {$[0.009]$} & {$[0.005]$} & {$[0.007]$} & {$[0.008]$} & {$[0.0000018]$} & {$[0.0000014]$} & {$[0.0000016]$} & {$[0.0000019]$} \\
\hline \multirow[t]{2}{*}{ Area of perennial crop land (m2) } & 0.002 & $0.010^{* *}$ & $0.021^{* * *}$ & $0.018^{* * *}$ & 0.0000006 & $0.0000027^{\star *}$ & $0.0000052^{* * *}$ & $0.0000047^{* * *}$ \\
\hline & {$[0.006]$} & {$[0.005]$} & [0.005] & {$[0.007]$} & {$[0.0000013]$} & {$[0.0000012]$} & [0.0000012] & [0.0000014] \\
\hline \multirow[t]{2}{*}{ Forestry land (m2) } & $0.006^{\star *}$ & -0.001 & -0.003 & -0.003 & $0.0000015^{*}$ & -0.0000003 & -0.0000011 & -0.000001 \\
\hline & {$[0.003]$} & [0.002] & {$[0.003]$} & [0.003] & [0.0000009] & {$[0.0000005]$} & {$[0.0000007]$} & [0.0000007] \\
\hline \multirow[t]{2}{*}{ Area of aquaculture water surface (m2) } & 0.02 & $0.030^{\star \star \star}$ & 0.017 & 0.017 & 0.0000043 & $0.0000096^{\star * *}$ & $0.0000070^{\star *}$ & $0.0000070^{* *}$ \\
\hline & [0.013] & {$[0.011]$} & {$[0.014]$} & {$[0.014]$} & [0.0000038] & {$[0.0000022]$} & {$[0.0000031]$} & [0.0000031] \\
\hline \multirow[t]{2}{*}{ Commune having non-farm activities } & $-185.442^{* *}$ & $-198.540^{\star \star}$ & -41.603 & -46.602 & $-0.06431^{* * *}$ & $-0.06598^{* * *}$ & -0.02965 & -0.02995 \\
\hline & [85.032] & [78.267] & {$[100.667]$} & [100.282] & [0.02027] & {$[0.01606]$} & {$[0.02288]$} & {$[0.02275]$} \\
\hline \multirow[t]{2}{*}{ Distance to nearest town $(\mathrm{km})$} & 1.276 & -3.593 & $-8.955^{\star *}$ & $-9.100^{* *}$ & 0.00107 & -0.0006 & $-0.00234^{* *}$ & $-0.00237^{* *}$ \\
\hline & [4.047] & [2.869] & [4.229] & [4.245] & {$[0.00111]$} & {$[0.00083]$} & {$[0.00110]$} & [0.00109] \\
\hline
\end{tabular}




\begin{tabular}{|c|c|c|c|c|c|c|c|c|}
\hline \multirow[b]{2}{*}{ Explanatory variables } & \multicolumn{4}{|c|}{ Dependent variable: Per capita expenditure } & \multicolumn{4}{|c|}{ Dependent variable: Logarithm of per capita expenditure } \\
\hline & $\begin{array}{c}\text { Model 1: } \\
\text { Fixed-effect }\end{array}$ & $\begin{array}{c}\text { Model 2: } \\
\text { Random } \\
\text { effect }\end{array}$ & $\begin{array}{l}\text { Model 3: } \\
\text { OLS }\end{array}$ & $\begin{array}{l}\text { Model 4: } \\
\text { IV }\end{array}$ & $\begin{array}{c}\text { Model 5: } \\
\text { Fixed-effect }\end{array}$ & $\begin{array}{c}\text { Model 6: } \\
\text { Random effect }\end{array}$ & $\begin{array}{l}\text { Model 7: } \\
\text { OLS }\end{array}$ & $\begin{array}{l}\text { Model 8: } \\
\text { IV }\end{array}$ \\
\hline \multirow[t]{2}{*}{ Distance to nearest road $(\mathrm{km})$} & 35.894 & $30.125^{\star \star \star}$ & $34.730^{* * *}$ & $35.322^{* \star *}$ & 0.00295 & $0.00642^{\star *}$ & $0.00890^{\star * \star}$ & $0.00885^{\star \star \star *}$ \\
\hline & [29.651] & [11.541] & [12.451] & [12.573] & [0.00519] & {$[0.00287]$} & [0.00299] & [0.00297] \\
\hline \multirow[t]{2}{*}{ Distance to nearest daily market $(\mathrm{km})$} & 7.328 & $-7.800^{\star *}$ & $-16.643^{\star \star}$ & $-17.083^{\star \star}$ & 0.00166 & $-0.00346^{\star * *}$ & $-0.00930^{\star \star *}$ & $-0.00915^{\star \star \star}$ \\
\hline & [6.072] & [3.733] & {$[6.826]$} & [6.677] & {$[0.00130]$} & [0.00099] & {$[0.00200]$} & [0.00197] \\
\hline \multirow[t]{2}{*}{ Distance to nearest periodic market $(\mathrm{km})$} & -2.141 & -2.531 & $-29.344^{* * *}$ & $-29.772^{\star * *}$ & -0.00067 & -0.00103 & $-0.00756^{\star * *}$ & $-0.00736^{* * *}$ \\
\hline & [4.787] & {$[4.077]$} & [7.426] & [7.498] & {$[0.00121]$} & [0.00099] & [0.00199] & [0.00199] \\
\hline \multirow[t]{2}{*}{ Distance to nearest post $(\mathrm{km})$} & $-10.523^{\star *}$ & $-14.368^{* * *}$ & $-17.676^{* *}$ & $-17.985^{\star \star \star}$ & $-0.00372^{\star * *}$ & $-0.00501^{* \star *}$ & $-0.00351^{*}$ & $-0.00364^{*}$ \\
\hline & [5.019] & [3.610] & [6.960] & [6.925] & [0.00135] & {$[0.00120]$} & {$[0.00193]$} & {$[0.00190]$} \\
\hline \multirow[t]{2}{*}{ Year 2008} & $451.777^{\star \star \star}$ & $366.697^{\star \star *}$ & & & $0.12966^{* * *}$ & $0.10351^{* * \star}$ & & \\
\hline & [37.449] & [35.081] & & & {$[0.00931]$} & {$[0.00878]$} & & \\
\hline Red River Delta & Omitted & & & & & & & \\
\hline \multirow[t]{2}{*}{ North East } & & $-189.344^{* *}$ & $-323.409^{* * *}$ & $-343.437^{\star * \star}$ & & $-0.06517^{* *}$ & $-0.09394^{\star \star *}$ & $-0.09615^{\star * *}$ \\
\hline & & [92.510] & [112.082] & [113.021] & & [0.02648] & [0.02924] & [0.02926] \\
\hline \multirow[t]{2}{*}{ North West } & & $-299.428^{\star *}$ & -136.261 & -196.882 & & $-0.18678^{\star \star \star}$ & $-0.10716^{\star \star}$ & $-0.11485^{\star *}$ \\
\hline & & [123.528] & [172.881] & [177.290] & & [0.04259] & [0.05222] & [0.05261] \\
\hline \multirow[t]{2}{*}{ North Central Coast } & & $-200.129^{\star *}$ & $-302.910^{\star * *}$ & $-316.375^{\star \star \star}$ & & $-0.08774^{\star \star \star}$ & $-0.10776^{\star \star \star}$ & $-0.10914^{\star \star \star}$ \\
\hline & & [83.708] & [105.745] & [105.541] & & [0.02529] & [0.02913] & [0.02898] \\
\hline \multirow[t]{2}{*}{ South Central Coast } & & $212.903^{\star *}$ & 174.441 & 153.874 & & $0.06441^{* *}$ & 0.0322 & 0.02996 \\
\hline & & [100.582] & [130.848] & [129.647] & & {$[0.02937]$} & [0.03383] & [0.03361] \\
\hline \multirow[t]{2}{*}{ Central Highlands } & & 43.188 & 114.78 & 55.23 & & $-0.06256^{\star}$ & -0.01886 & -0.02795 \\
\hline & & [118.826] & [167.408] & [176.044] & & {$[0.03607]$} & {$[0.04667]$} & [0.04806] \\
\hline \multirow[t]{2}{*}{ North East South } & & $1321.041^{\star \star \star}$ & $1503.411^{\star \star \star}$ & $1507.550^{\star \star \star}$ & & $0.32822^{\star * \star}$ & $0.34042^{\star \star \star}$ & $0.34022^{* \star *}$ \\
\hline & & [149.064] & [203.907] & [200.913] & & [0.03248] & {$[0.03746]$} & [0.03719] \\
\hline \multirow[t]{2}{*}{ Mekong River Delta } & & $775.163^{\star * *}$ & $672.015^{\star \star *}$ & $749.269^{\star \star *}$ & & $0.23169^{* * *}$ & $0.19538^{* * *}$ & $0.20387^{* * *}$ \\
\hline & & [115.672] & [152.590] & [162.300] & & [0.02742] & {$[0.03317]$} & [0.03551] \\
\hline \multirow[t]{2}{*}{ Constant } & $3841.43^{\star \star *}$ & $1977.73^{\star \star \star}$ & $1777.18^{\star \star *}$ & $1677.43^{\star \star *}$ & $7.94997^{\star * \star}$ & $7.50379^{\star \star *}$ & $7.49063^{* * *}$ & $7.48028^{* * *}$ \\
\hline & [848.153] & [393.784] & [503.803] & [499.960] & [0.21306] & [0.10635] & [0.13217] & [0.13182] \\
\hline Observations & 6198 & 6198 & 3099 & 3099 & 6198 & 6198 & 3099 & 3099 \\
\hline Number of $\mathrm{i}$ & 3099 & 3099 & & & 3099 & 3099 & & \\
\hline R-squared & 0.28 & 0.33 & 0.38 & & 0.34 & 0.42 & 0.48 & \\
\hline
\end{tabular}


Table A.3. Tests on weak instruments and underidentification of IV, and endogeneity of crop sales in IV regressions

\begin{tabular}{lcc}
\hline & $\begin{array}{c}\text { Per capita expenditure } \\
\text { (Model 4) }\end{array}$ & $\begin{array}{c}\text { Logarithm of per capita } \\
\text { expenditure (Model 8) }\end{array}$ \\
\hline Underidentification test of IV: Hansen J statistic & $\begin{array}{c}\chi_{(1)}=886.04 \\
\text { P-value }=0.000\end{array}$ & $\begin{array}{c}\chi_{(1)}=886.04 \\
\text { P-value }=0.000\end{array}$ \\
Test of endogeneity: Durbin-Wu-Hausman statistic & $\begin{array}{c}\chi_{(1)}=1.772 \\
\text { P-value }=0.777\end{array}$ & $\begin{array}{c}\chi_{(1)}=1.799 \\
\text { P-value }=0.773\end{array}$ \\
Weak IV identification test: Cragg-Donald F statistic & 253.526 & 253.526 \\
\hline
\end{tabular}

Source: Estimation from the 2004 VHLSS. 